\title{
Power Quality Improvement using Installation of Bank Capacitors in Office Building
}

\author{
Ramadoni Syahputra and Agus Jamal \\ Department of Electrical Engineering, Faculty of Engineering, \\ Universitas Muhammadiyah Yogyakarta \\ Jl. Ringroad Barat Tamantirto, Kasihan, 55183 Yogyakarta, Indonesia \\ e-mail: ramadoni@umy.ac.id, ajamal_me@yahoo.co.id
}

\begin{abstract}
This study discusses the analysis and realization of electrical power quality improvement of office building with case study at Universitas Muhammadiyah Yogyakarta (UMY) rectorate building. One of the important variables in determining the electrical power quality of a system is the load power factor on the consumer side. The power factor depends on the type of load being served. In office buildings generally, the largest electrical load is a cooling device. This air conditioner in its operation using electric motor components. An electric motor is an electrical load that has a bad power factor. With this fact, the electrical load of electric motors on the air conditioner contributes greatly to the overall bad power load factor. In this study, a case study on electrical power quality audit at the UMY rectorate building was conducted. Based on the audit results obtained data that the power factor of the building is still below the standard, so, it needs to be done power factor improvement. The results showed that the calculation of capacities and types of capacitor bank are useful to improve the power factor of UMY rectorate building.
\end{abstract}

Key words: Power quality, office building, power factor, inductive load, harmonics, electric motor, air conditioner

\section{INTRODUCTION}

The power factor or working factor is the ratio of the active power (watt) to the total power (VA) or the cosine of the angle between active power and total power (Sadaat, 1998; Jamal and Syahputra, 2013; Syahputra et al., 2016). High reactive power will increase this angle and as a result the power factor will be lower. The power factor is always smaller or equal to one (Syahputra et al., 2014a and b; 2015a-c; Syahputra and Soesanti, 2016a-d).

Theoretically, if the entire power load supplied by the power company has a power factor of one then the maximum power transferred equals the capacity of the distribution system (Syahputra et al., 2014a, b). Thus, with the load induced and if the power factor ranges from 0.2-0.5 the capacity of the power distribution network becomes depressed. Thus, the reactive power (VAR) should be as low as possible for the same $\mathrm{kW}$ output in order to minimize the total power requirement (VA) (Syahputra et al., 2015a-c; Syahputra and Soesanti, 2016a-6; Soesanti and Syahputra, 2016; Tang et al., 2017; Ahmed and Salam, 2018; Syahputra et al., 2014 a, b; 2015a-c). Power factor describes the phase angle between active power and apparent power. Low power factor is detrimental because it results in high load current. These power factor improvements use capacitors (Ashari and Syahputra, 2014; Syahputra and Soesanti, 2016a-d; Jamal et al., 2015; Syahputra and Soesanti, 2015; Syahputra, 2017a, b).

Power factor plays an important role in determining the power quality of a power system including electrical systems in office buildings. A good power factor is also able to save significant electrical energy consumption (Syahputra, 2016a, b; Syahputra and Soesanti, 2016a-d; Syahputra et al., 2012; Syahputra, 2017a, b). However, it is important to carefully calculate the capacitor capacities required for the improvement of power factor. A lot of research has been done to improve power factor of electric power system, among others improvement of load motor power factor, power factor improvement on industry and others (Andrei et al., 1993, 2001; Jamal and Syahputra, 2016).

In this research, the power factor improvement on the electrical installation of the multi-storey building uses the bank capacitor. The object of research is the rectorate

Corresponding Author: Ramadoni Syahputra, Department of Electrical Engineering, Faculty of Engineering, Universitas Muhammadiyah Yogyakarth, Jl. Ringroad Barat Tamantirto, Kasihan, 55183 Yogyakarta, Indonesia, e-mail: ramadoni@umy.ac.id 
building of Muhammadiyah University of Yogyakarta. First of all do the audit of electrical energy on the installation of the building. This energy audit aims to get actual data about power factor condition. Based on the actual conditions then calculations are made to determine the capacity of capacitors needed to increase the power factor of the system. Next is the installation of power capacitors on the electrical installation of the building. After the power capacitor is installed then the power factor measurement and some other variables. The results of the measurements were analyzed to obtain conclusions about the successful installation of bank capacitors for the improvement of electric power factor.

\section{Power quality in power system \\ Fundamental of p o wer factor: The advantages of power factor improvement through the installation of capacitors are (Syahputra and Soesanti, 2016a-d; Syahputra, 2016a, b).}

For consumer, especially company or industry: Only one investment is required for the purchase and installation of capacitors and no ongoing costs. Reduce the cost of electricity for the company because reactive power (kVAR) is no longer supplied by utility companies so total demand (kVA) is reduced and the value of a fine paid if operating at a low power factor can be avoided. Reduced distribution loss ( $\mathrm{kWh}$ ) in network/factory installation. The voltage level at the end load increases, so as to improve motor performance.

For electric utility suppliers: The reactive component on the network and the total current in the end-end system is reduced. The loss of power $I^{2} R$ in the system decreases due to the decrease of the current. The capacity of power distribution networks increases, reducing the need to install additional capacity. How to install the installation of capacitors can be divided into 3 parts, namely:

Global compensation: Along with this method the capacitor is installed in the parent panel. The descending current from the installation of this model is only in the interface between the MDP panel and the transformer. While the current passing after the MDP does not decrease thereby the loss due to heat dissipation in the conductor after MDP is not affected. Moreover, the installation of power with a fairly long delivery delta voltage is still quite large.

Sectoral compensation: With this method a capacitor composed of several capacitor panels mounted in the SDP panel. This method is suitable for industries with large installed load capacity up to thousands of kVA and the distance between the MDP and SDP panels is quite far a part.

Individual compensation: With this method the capacitor is directly mounted on each load, especially having a large power. This method is actually more effective and better from the technical point of view. But there are drawbacks that must provide a space or a special place to put the capacitor, so as to reduce the aesthetic value.

Low power factor arises from a load with inductive manner that draws a large amount of reactive power to produce the magnetic field that it needs to operate. The reactive power needed by the load can be drawn from the generator but this causes large losses to be incurred on the power distribution system. To reduce these losses and raise the power factor of the system, reactive power needs to be injected into the power system fairly close to the load. There are several ways to generate the reactive power in an electrical power system.

A very economical reactive power generator is using a capacitor bank in passive installation. If a capacitor is energized then the voltage across the terminals cannot change instantaneously. When an AC voltage is placed on the capacitor the current waveform will be a sine wave like the source voltage but its phase will be $90^{\circ}$ ahead of the voltage wave form. This leading current when injected into the power system by the capacitor bank will offset the lagging current of the inductive load.

The capacitor bank is charged and discharged two times during the $\mathrm{AC}$ voltage cycle. An inductor is also charged and discharged during the same cycle. The phase shifts between the current and voltage in inductors and capacitors show that the inductor is charging at the same time that the capacitor is discharging and vice versa. This relationship shows how the capacitors supply the reactive power that the inductive circuits need for magnetic fields. In construction, capacitors are constructed by winding aluminum foil and a dielectric material into circular coils (Syahputra, 2017a, b). These coils are then connected in series and parallel combination and stacked together in an insulated container. When designing a capacitor the number of coils the length and the width of the foil and the thickness of the insulating dielectric material needs to be determined. Once, the size and the number of coils are determined the size of the required capacitor container can be calculated. For our design we will use polypropylene as the insulating material and aluminum foil as the conductor.

Voltage drop across a distribution line is caused by the increasing amount of current that is drawn by the loads. This means there is a high consumption of reactive 


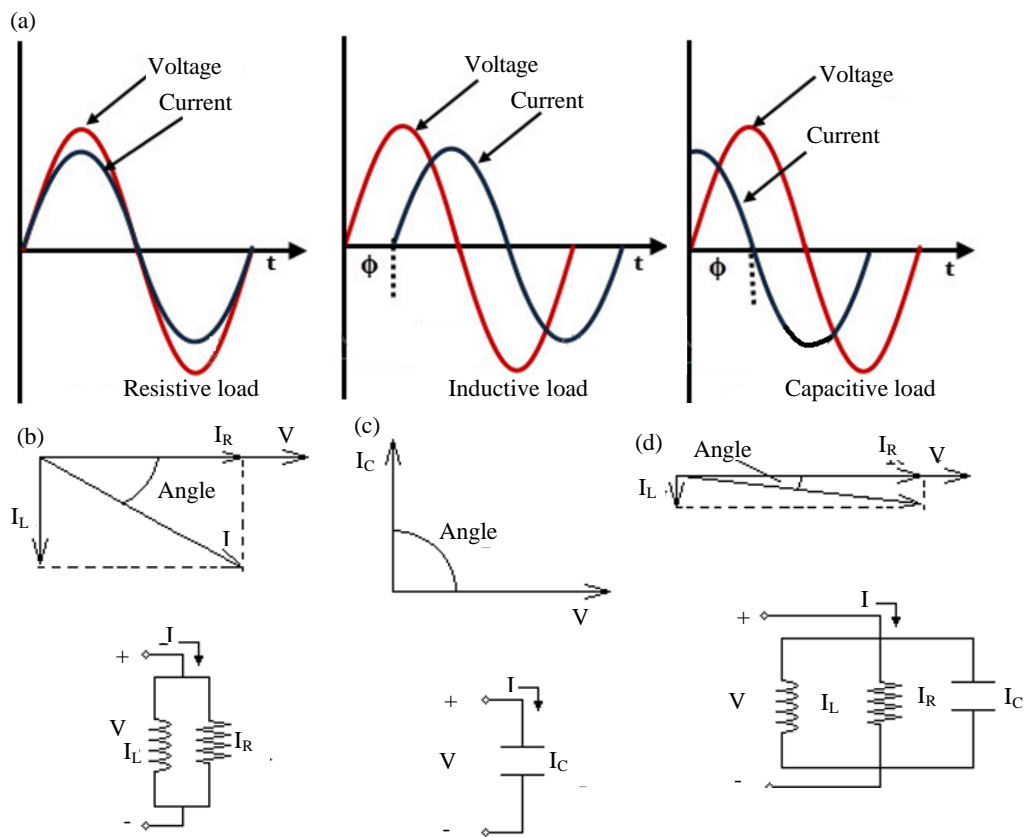

Fig. 1: a) Effect of capacitor for the power factor improvement; b) Without capacitor; c) Capacitive load (supplied by capacitor) and d) Load after adding capacitor

power by the loads especially big motors or generators. When one of these monsters starts there will be a significant voltage drop across the distribution line as more and more current is needed. In order to solve the problem of voltage drop, capacitors are used. Capacitors have been known to store energy and this energy is reactive. Reactive power can now be supplied to big motors and generators and this eventually decrease the demand of reactive power from the distribution center or substation. If it is being solved, energy can be used in the most optimum level in the system. These capacitors will be activated once there is a need for reactive power. The effect can be shown in Fig. 1 .

Power factor improvement: Most industrial loads such as induction motors operate at moderately low power factors. Around $60 \%$ of the utility load consists of motors and hence, the overall power factor of the power system is low. Depending on the level of the load these motors are inherently low power factor devices. The power factor of these motors varies from $0.30-0.95$, depending on the size of the motor and other operating conditions. Therefore, the power factor level is always a concern for industrial power systems, utilities and the user. The system performance can be improved by correcting the power factor. The system power factor is given by:

$$
\text { Power factor }=\mathrm{P} / \mathrm{kVA}
$$

where, $\mathrm{P}$ and $\mathrm{kVA}$ are the real and apparent power, respectively. The relation between the power factor and the $\mathrm{Q} / \mathrm{P}$ ratio is shown in Fig. 1. Figure 1, it can be seen that even at $90 \%$ power factor the reactive power requirement is $48 \%$ of the real power. At low power factors the reactive power demand is much higher. Therefore, some form of power factor correction is required in all the industrial facilities.

The power factor in a power system can leading or lagging, depends on the load of the system. The direction of active and reactive power can be used to determine the nature of the power factor. If both the real and reactive power flow are in the same direction then the power factor is lagging. If the reactive power flows in the direction opposite to that of the real power then the power factor is leading. A typical lagging power factor load is an induction motor. A typical leading power factor load is a capacitor. Generally, power factor improvement can be made for three reasons in industrial plant.

Using shunt capacitors to supply the leading currents required by the load relieves the generator from supplying that part of the inductive current. The system benefits due to the application of shunt capacitors include:

- Reactive power support

- Voltage profile improvements

- Line and transformer loss reductions 
- Release of power system capacity

- Savings due to increased energy loss

In distribution systems the voltage at the load end tends to get lower due to the lack of reactive power. In such cases, local VAR support is offered using shunt capacitors. In the case of long transmission lines the reactive power available at the end of the line during peak load conditions is small and hence, needs to be supplied using shunt capacitors. The reactive power drawn from the supply is substantially less and the kVA and the current flows are less. The power factor at the load is improved. The shunt capacitors reduce the amount of inductive current in an electric circuit. The reduction in the line current decreases the IR and IX voltage drops there by improving the voltage level of the system from the capacitor location back to the source.

\section{MATERIALS AND METHODS}

In this research, efforts to improve the power factor in the installation of office buildings. The location of the research is the office building on the rectorate building of Universitas Muhammadiyah Yogyakarta. The main target in this research is the improvement of power factor using the installation of capacitor bank. Based on the theory the installation of capacitors is also able to increase the system voltage profile. With the improvement of power factor system then the energy saving of electricity will also be obtained because electric power can be utilized optimally.

The research steps are: Conducting audit of electrical installation at the rectorate building of Universitas Muhammadiyah Yogyakarta. This audit is done to get actual data about electrical installation that is voltage, current, power factor, harmonics and system frequency. Conducting the design of proper electrical installation to improve the system power factor, including the installation plan of the capacitor installation. Perform capacitor capacity calculations to be used for power factor improvement while improving the system voltage profile using the power factor improvement table as shown in Fig. 2.

Conducting the installation of bank capacitors on the installation of the rectorate building of Universitas Muhammadiyah Yogyakarta. Conducting measurements of voltage, frequency and power factor after the installation of the capacitor. Conducting an analysis of the results of the installation of a bank capacitor for the improvement of power factor and the system voltage profile. Make conclusions and recommendations.

\begin{tabular}{|c|c|c|c|c|c|c|c|c|c|c|c|c|c|}
\hline \multicolumn{14}{|c|}{ Factor K ( kvar/kW ) } \\
\hline \multirow[b]{2}{*}{ initial $\cos \varphi$} & \multicolumn{13}{|c|}{ final $\cos \varphi$} \\
\hline & 0.80 & 0.85 & 0.90 & 0.91 & 0.92 & 0.93 & 0.94 & 0.95 & 0.96 & 0.97 & 0.98 & 0.99 & 1 \\
\hline 0.60 & 0.583 & 0.714 & 0.849 & 0.878 & 0.907 & 0.938 & 0.970 & 1.005 & 1.042 & 1.083 & 1.130 & 1.191 & 1.333 \\
\hline 0.61 & 0.549 & 0.679 & 0.815 & 0.843 & 0.873 & 0.904 & 0.936 & 0.970 & 1.007 & 1.048 & 1.096 & 1.157 & 1.299 \\
\hline 0.62 & 0.515 & 0.646 & 0.781 & 0.810 & 0.839 & 0.870 & 0.903 & 0.937 & 0.974 & 1.015 & 1.062 & 1.123 & 1.265 \\
\hline 0.63 & 0.483 & 0.613 & 0.748 & 0.777 & 0.807 & 0.837 & 0.870 & 0.904 & 0.941 & 0.982 & 1.030 & 1.090 & 1.233 \\
\hline 0.64 & 0.451 & 0.581 & 0.716 & 0.745 & 0.775 & 0.805 & 0.838 & 0.872 & 0.909 & 0.950 & 0.998 & 1.058 & 1.201 \\
\hline 0.65 & 0.419 & 0.549 & 0.685 & 0.714 & 0.743 & 0.774 & 0.806 & 0.840 & 0.877 & 0.919 & 0.966 & 1.027 & 1.169 \\
\hline 0.66 & 0.388 & 0.519 & 0.654 & 0.683 & 0.712 & 0.743 & 0.775 & 0.810 & 0.847 & 0.888 & 0.935 & 0.996 & 1.138 \\
\hline 0.67 & 0.358 & 0.488 & 0.624 & 0.652 & 0.682 & 0.713 & 0.745 & 0.779 & 0.816 & 0.857 & 0.905 & 0.966 & 1.108 \\
\hline 0.68 & 0.328 & 0.459 & 0.594 & 0.623 & 0.652 & 0.683 & 0.715 & 0.750 & 0.787 & 0.828 & 0.875 & 0.936 & 1.078 \\
\hline 0.69 & 0.299 & 0.429 & 0.565 & 0.593 & 0.623 & 0.654 & 0.686 & 0.720 & 0.757 & 0.798 & 0.846 & 0.907 & 1.049 \\
\hline 0.70 & 0.270 & 0.400 & 0.536 & 0.565 & 0.594 & 0.625 & 0.657 & 0.692 & 0.729 & 0.770 & 0.817 & 0.878 & 1.020 \\
\hline 0.71 & 0.242 & 0.372 & 0.508 & 0.536 & 0.566 & 0.597 & 0.629 & 0.663 & 0.700 & 0.741 & 0.789 & 0.849 & 0.992 \\
\hline 0.72 & 0.214 & 0.344 & 0.480 & 0.508 & 0.538 & 0.569 & 0.601 & 0.635 & 0.672 & 0.713 & 0.761 & 0.821 & 0.964 \\
\hline 0.73 & 0.186 & 0.316 & 0.452 & 0.481 & 0.510 & 0.541 & 0.573 & 0.608 & 0.645 & 0.686 & 0.733 & 0.794 & 0.936 \\
\hline 0.74 & 0.159 & 0.289 & 0.425 & 0.453 & 0.483 & 0.514 & 0.546 & 0.580 & 0.617 & 0.658 & 0.706 & 0.766 & 0.909 \\
\hline 0.75 & 0.132 & 0.262 & 0.398 & 0.426 & 0.456 & 0.487 & 0.519 & 0.553 & 0.590 & 0.631 & 0.679 & 0.739 & 0.882 \\
\hline 0.76 & 0.105 & 0.235 & 0.371 & 0.400 & 0.429 & 0.460 & 0.492 & 0.526 & 0.563 & 0.605 & 0.652 & 0.713 & 0.855 \\
\hline 0.77 & 0.079 & 0.209 & 0.344 & 0.373 & 0.403 & 0.433 & 0.466 & 0.500 & 0.537 & 0.578 & 0.626 & 0.686 & 0.829 \\
\hline 0.78 & 0.052 & 0.183 & 0.318 & 0.347 & 0.376 & 0.407 & 0.439 & 0.474 & 0.511 & 0.552 & 0.599 & 0.660 & 0.802 \\
\hline 0.79 & 0.026 & 0.156 & 0.292 & 0.320 & 0.350 & 0.381 & 0.413 & 0.447 & 0.484 & 0.525 & 0.573 & 0.634 & 0.776 \\
\hline 0.80 & & 0.130 & 0.266 & 0.294 & 0.324 & 0.355 & 0.387 & 0.421 & 0.458 & 0.499 & 0.547 & 0.608 & 0.750 \\
\hline 0.81 & & 0.104 & 0.240 & 0.268 & 0.298 & 0.329 & 0.361 & 0.395 & 0.432 & 0.473 & 0.521 & 0.581 & 0.724 \\
\hline 0.82 & & 0.078 & 0.214 & 0.242 & 0.272 & 0.303 & 0.335 & 0.369 & 0.406 & 0.447 & 0.495 & 0.556 & 0.698 \\
\hline 0.83 & & 0.052 & 0.188 & 0.216 & 0.246 & 0.277 & 0.309 & 0.343 & 0.380 & 0.421 & 0.469 & 0.530 & 0.672 \\
\hline 0.84 & & 0.026 & 0.162 & 0.190 & 0.220 & 0.251 & 0.283 & 0.317 & 0.354 & 0.395 & 0.443 & 0.503 & 0.646 \\
\hline 0.85 & & & 0.135 & 0.164 & 0.194 & 0.225 & 0.257 & 0.291 & 0.328 & 0.369 & 0.417 & 0.477 & 0.620 \\
\hline 0.86 & & & 0.109 & 0.138 & 0.167 & 0.198 & 0.230 & 0.265 & 0.302 & 0.343 & 0.390 & 0.451 & 0.593 \\
\hline 0.87 & & & 0.082 & 0.111 & 0.141 & 0.172 & 0.204 & 0.238 & 0.275 & 0.316 & 0.364 & 0.424 & 0.567 \\
\hline 0.88 & & & 0.055 & 0.084 & 0.114 & 0.145 & 0.177 & 0.211 & 0.248 & 0.289 & 0.337 & 0.397 & 0.540 \\
\hline 0.89 & & & 0.028 & 0.057 & 0.086 & 0.117 & 0.149 & 0.184 & 0.221 & 0.262 & 0.309 & 0.370 & 0.512 \\
\hline 0.90 & & & & 0.029 & 0.058 & 0.089 & 0.121 & 0.156 & 0.193 & 0.234 & 0.281 & 0.342 & 0.484 \\
\hline
\end{tabular}

Fig. 2: The power factor improvement table for determining the capacitor 


\section{RESULTS AND DISCUSSION}

In this research there are several variables observed are frequency system, system voltage profile, harmonic system and system power factor. This observation is done by doing direct measurement on electric installation of rectorate building of Universitas Muhammadiyah Yogyakarta using power analyzer measuring instrument. The measurement results are shown in Fig. 3-6.

Figure 3 shows frequency of the electrical installation system of rectorate building of Universitas Muhammadiyah Yogyakarta. As shown in the figure that in general the system frequency is relatively stable. Measurements are made for $24 \mathrm{~h}$. However, if it is observed in detail that there is frequency fluctuation in the first $4 \mathrm{~h}$ of measurement, although, not large. The maximum frequency of measurement results is $50.3 \mathrm{~Hz}$. This increase in frequency occurs when activity in the office building undergoes a shift from activities that are packed to the same activity which occurs at 11:30 AM 01:00 PM. At this time activity in the office building is quiet because the employees are resting. However, this frequency change is not large, so, overall it does not really affect the system.

Figure 4 shows the voltage profile for phase to neutral of the electrical installation system of rectorate building of Universitas Muhammadiyah Yogyakarta. This voltage profile is a system voltage profile after installation of a capacitor bank with a capacity of $35 \mathrm{kVAR}$. It can be seen that phase 1 voltage is $211.1 \mathrm{~V}$, phase 2 voltage is 216.4 volt and phase 3 voltage is $216.0 \mathrm{~V}$. RMS voltage phase 1 is the lowest voltage measurement result. This is because in phase 1 there is a relatively greater load than the other two phases, so that, the phase voltage is significantly decreased compared to other phases. However, with the installation of the bank capacitor the voltage of each phase is still within tolerable limits.

Figure 5 shows the voltage profile for phase to phase of the electrical installation system of rectorate building of Universitas Muhammadiyah Yogyakarta. This voltage profile is a system voltage profile after installation of a capacitor bank with a capacity of $35 \mathrm{kVAR}$. It can be seen that phase 1 voltage is $368.0 \mathrm{~V}$, phase 2 voltage is 377.7 volt and phase 3 voltage is $369.1 \mathrm{~V}$. RMS voltage phase 1 is the lowest voltage measurement result. This is because in phase 1 there is a relatively greater load than the other two phases, so that, the phase voltage is significantly decreased compared to other phases. However with the installation of the bank capacitor the voltage of each phase is still within tolerable limits. The highest phase to phase voltage occurs in phase 2 because the load under this phase is relatively lighter than the other phase.

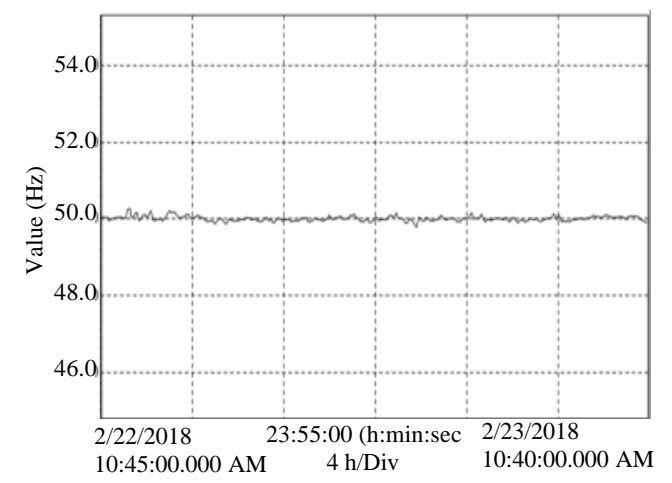

Fig. 3: Frequency of the electrical installation system of rectorate building of Universitas Muhammadiyah Yogyakarta

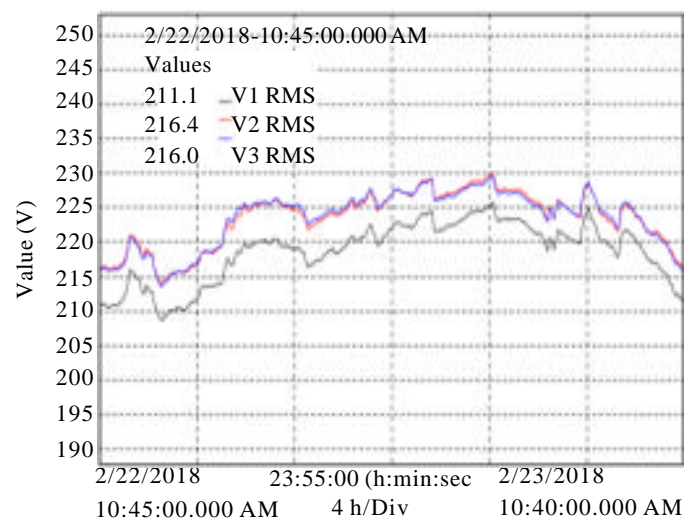

Fig. 4: Voltage profile for phase to neutral of the electrical installation system of rectorate building of Universitas Muhammadiyah Yogyakarta

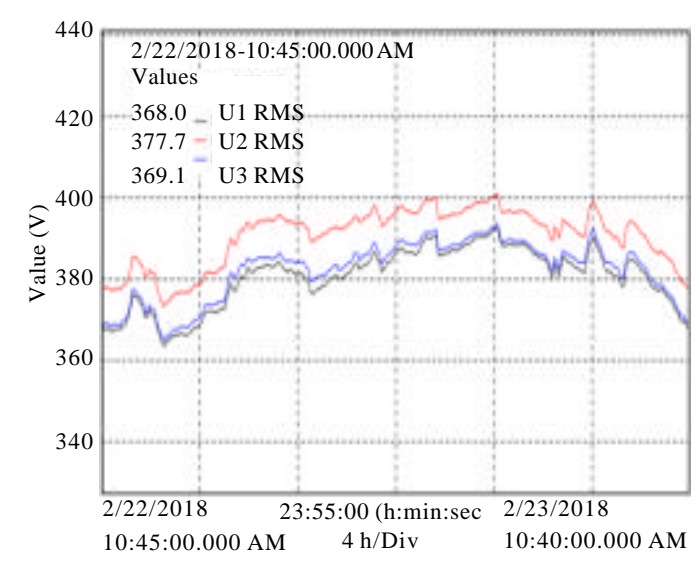

Fig. 5: Voltage profile for phase to phase of the electrical installation system of rectorate building of Universitas Muhammadiyah Yogyakarta 


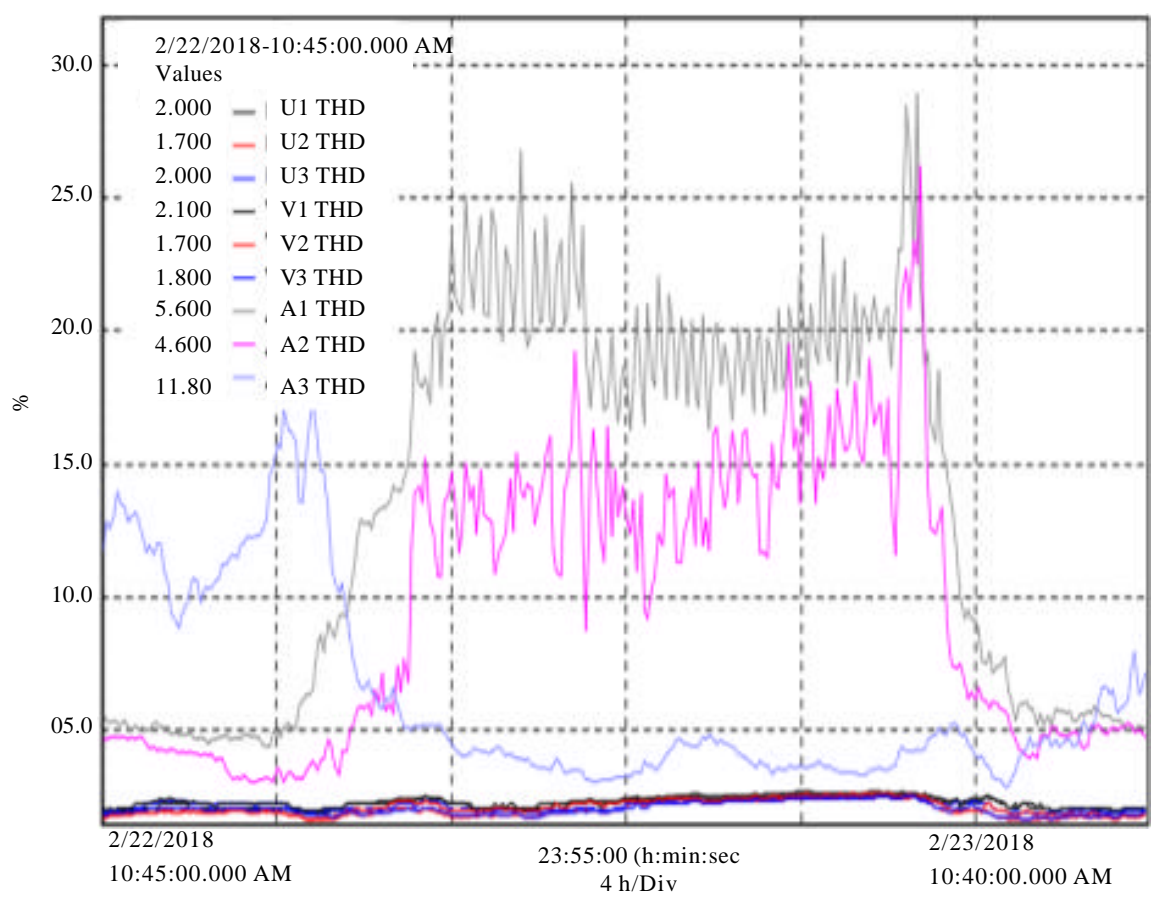

Fig. 6: Total Harmonic Distortion (THD) of the electrical installation system of rectorate building of Universitas Muhammadiyah Yogyakarta

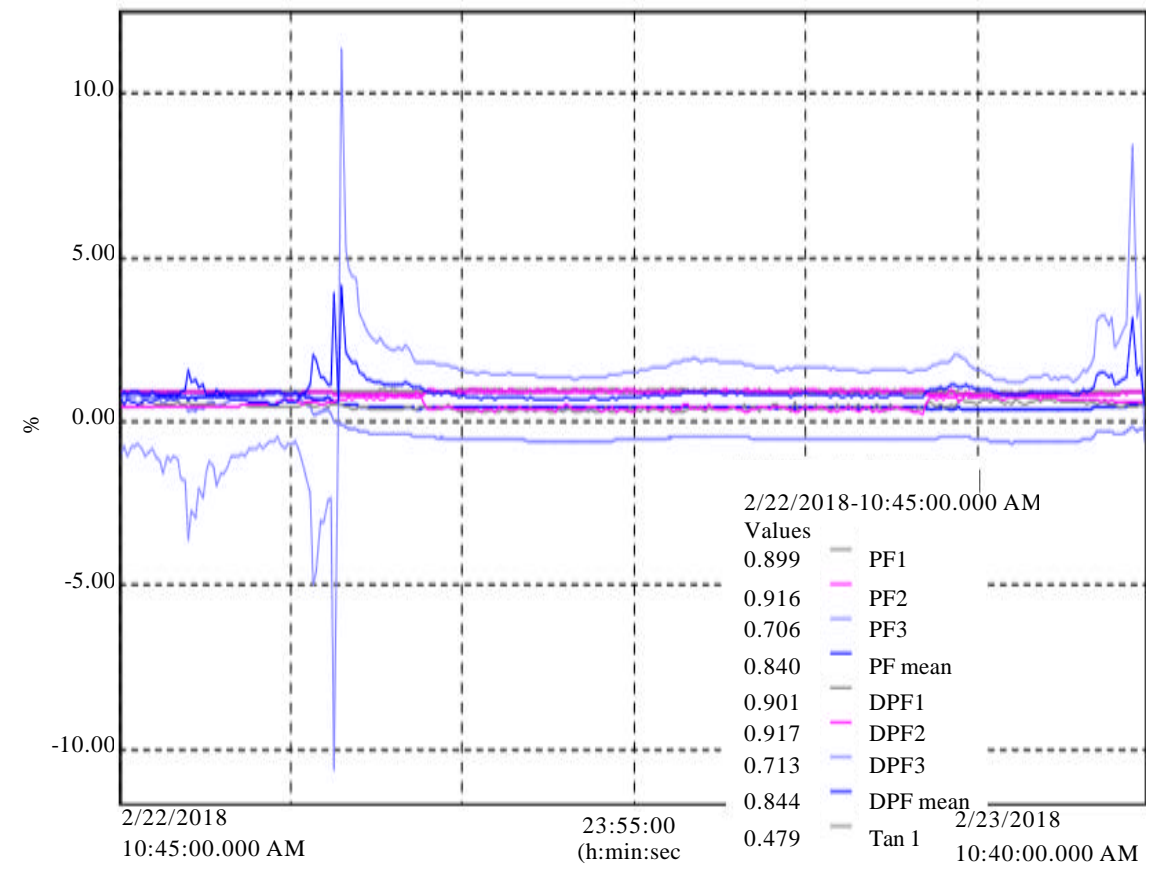

Fig. 7: Power factor of the electrical installation system of rectorate building of Universitas Muhammadiyah Yogyakarta

Figure 6 and 7 shows the Total Harmonic Distortion (THD) of the electrical installation system of rectorate building of Universitas Muhammadiyah Yogyakarta. The
THD is the result of observation after the installation of capacitor of $35 \mathrm{kVAR}$. It appears that in general THD has decreased significantly. The highest THD occurs in the 
phase of A3 that is $11.80 \%$. This THD value exceeds the expected threshold of 5\% maximum. However, in other phases the THD is relatively small under $5 \%$, according to, IEC standard.

Figure 7 shows the power factor of the electrical installation system of rectorate building of Universitas Muhammadiyah Yogyakarta. This power factor is a system power factor after installation of a capacitor bank with a capacity of $35 \mathrm{kVAR}$. It can be seen in the figure that the average power factor of the system is 0.840 . This power factor is relatively better compared to before the capacitor is 0.682. Based on the measurement results obtained that power factor phase 1 is 0.899 , power factor phase 2 is 0.916 and power factor phase 3 is 0.706 . Power factor phase 3 is the lowest because in this phase there are many electrical loads are inductive, i.e., electric motors on the air conditioner.

\section{CONCLUSION}

In this research there are several variables observed are frequency system, system voltage profile, harmonic system and system power factor. This observation is done by doing direct measurement on electric installation of rectorate building of Universitas Muhammadiyah Yogyakarta using power analyzer measuring instrument. Installation of $35 \mathrm{kVAR}$ capacitors can improve the quality of system power well. One indicator of power quality is the power factor of the system. The result of the bank capacitor installation has improved the system power factor from 0.682-0.840. Installation of capacitors proven to improve system performance.

\section{ACKNOWLEDGEMENT}

The researchers gratefully acknowledge the contributions of the directorate general of development and research enhancement, Ministry of Research, Technology and Higher Education of the republic of Indonesia for funding this research.

\section{REFERENCES}

Ahmed, J. and Z. Salam, 2018. An enhanced adaptive P\&O MPPT for fast and efficient tracking under varying environmental conditions. IEEE. Trans. Sustainable Energy, 9: 1487-496.

Andrei, R.G., A.J.F. Keri, R.J. Albanese and P.B. Johnson, 1993. Bridge capacitor bank installation concept reactive power generation in EHV systems. IEEE. Trans. Power Syst., 8: 1463-1470.
Andrei, R.G., M. Ahmed, H.K. Tumageanian and J.C. Smith, 2001. Worlds first commercial bridge capacitor bank installation on the American electric power system. IEEE. Trans. Power Delivery, 16: 342-345.

Ashari, M. and R. Syahputra, 2014. Power loss reduction strategy of distribution network with distributed generator integration. Proceedings of the 2014 1st International Conference on Information Technology, Computer and Electrical Engineering (ICITACEE), November 8, 2014, IEEE, Semarang, Indonesia, ISBN:978-1-4799-6431-4, pp: 404-408.

Jamal, A. and R. Syahputra, 2013. UPFC based on adaptive neuro-fuzzy for power flow control of multimachine power systems. Intl. J. Eng. Sci. Invention, 2: 5-14.

Jamal, A. and R. Syahputra, 2016. Heat exchanger control based on artificial intelligence approach. Intl. J. Appl. Eng. Res., 11: 9063-9069.

Jamal, A., S. Suripto and R. Syahputra, 2015. Multi-band power system stabilizer model for power flow optimization in order to improve power system stability. J. Theor. Appl. Inf. Technol., 81: 116-123.

Sadaat, H., 1998. Power System Analysis. 2nd Edn., McGraw-Hill, New York, USA., ISBN:9780075616344, Pages: 697.

Soesanti, I. and R. Syahputra, 2016. Batik production process optimization using particle swarm optimization method. J. Theor. Appl. Inf. Technol., 86: 272-278.

Syahputra, R. and I. Soesanti, 2015. Power system stabilizer model based on fuzzy-PSO for improving power system stability. Proceedings of the 2015 International Conference on Advanced Mechatronics, Intelligent Manufacture and Industrial Automation (ICAMIMIA), October 15-17, 2015, IEEE, Surabaya, Indonesia, ISBN:978-1-4673-7347-0, pp: 121-126.

Syahputra, R. and I. Soesanti, 2016c. An optimal tuning of pss using ais algorithm for damping oscillation of multi-machine power system. J. Theor. Appl. Inf. Technol., 94: 312-326.

Syahputra, R. and I. Soesanti, 2016b. Application of green energy for batik production process. J. Theor. Appl. Inf. Technol., 91: 249-256.

Syahputra, R. and I. Soesanti, 2016d. DFIG control scheme of wind power using ANFIS method in electrical power grid system. Intl. J. Appl. Eng. Res., 11: 52565262.

Syahputra, R. and I. Soesanti, 2016a. Design of automatic electric batik stove for batik industry. J. Theor. Appl. Inf. Technol., 87: 167-175. 
Syahputra, R., 2016a. Application of neuro-fuzzy method for prediction of vehicle fuel consumption. J. Theor. Appl. Inf. Technol., 86: 138-149.

Syahputra, R., 2016b. Power system stabilizer model using artificial immune system for power system controlling. Intl. J. Appl. Eng. Res., 11: 9269-9278.

Syahputra, R., 2017b. B16-Performance analysis of a wind turbine with permanent magnet synchronous generator. J. Theor. Appl. Inf. Technol., 95: 1950-1957.

Syahputra, R., 2017a. Distribution network optimization based on genetic algorithm. J. Electr. Technol. UMY., 1: $1-9$

Syahputra, R., I. Robandi and M. Ashari, 2012. Reconfiguration of distribution network with DG using fuzzy multi-objective method. Proceedings of the 2012 International Conference on Innovation Management and Technology Research (ICIMTR), May 21-22, 2012, IEEE, Malacca, Malaysia, ISBN:9781-4673-0655-3, pp: 316-321.

Syahputra, R., I. Robandi and M. Ashari, 2014a. Optimal distribution network reconfiguration with penetration of distributed energy resources. Proceedings of the 2014 1st International Conference on Information Technology, Computer and Electrical Engineering (ICITACEE), November 8, 2014, IEEE, Semarang, Indonesia, ISBN:978-1-4799-6431-4, pp: 388-393.
Syahputra, R., I. Robandi and M. Ashari, 2014b. Optimization of distribution network configuration with integration of distributed energy resources using extended fuzzy multi-objective method. Intl. Rev. Electr. Eng., 9: 629-639.

Syahputra, R., I. Robandi and M. Ashari, 2015c. PSO based multi-objective optimization for reconfiguration of radial distribution network. Intl. J. Appl. Eng. Res., 10: 14573-14586.

Syahputra, R., I. Robandi and M. Ashari, 2015a. Performance improvement of radial distribution network with distributed generation integration using extended particle swarm optimization algorithm. Intl. Rev. Electr. Eng., 10: 293-304.

Syahputra, R., I. Robandi and M. Ashari, 2015b. Reconfiguration of distribution network with distributed energy resources integration using PSO algorithm. Telkomnika Telecommun. Comput. Electron. Contr., 13: 759-766.

Syahputra, R., I. Soesanti and M. Ashari, 2016. Performance enhancement of distribution network with DG integration using modified PSO algorithm. J. Electr. Syst., 12: 1-19.

Tang, L., W. Xu and C. Mu, 2017. Analysis for step-size optimisation on MPPT algorithm for photovoltaic systems. IET. Power Electron., 10: 1647-1654. 